PROFESI, Volume 14, Nomor 2 Maret 2017

\title{
HUBUNGAN ANTARA AKTIFITAS FISIK DAN HIPERTENSI PADA LANSIA
}

\section{THE RELATIONSHIP BETWEEN PHISICAL ACTIVITIES AND HIPERTENSION}

\author{
Sri Iswahyuni \\ AKPER Mamba'ul 'Ulum Surakarta \\ email: iswahyunisri@yahoo.co.id
}

\begin{abstract}
Abstrak
Aktifitas fisik adalah setiap gerakan tubuh yang dihasilkan oleh otot rangka yang memerlukan pengeluaran energi. Hipertensi adalah suatu keadaan dimana tekanan sistole dan diastole mengalami kenaikan yang melebihi batas normal tekanan (tekanan sistol diatas $140 \mathrm{mmHg}$ dan diastol diatas $90 \mathrm{mmHg}$ ) (Murwani, 2011 :81). Tujuan penelitian ini mengetahui hubungan aktivitas fisik dan Hipertensi pada Lansia di Desa Jetiskarangpung, Kalijambe, Sragen. Populasinya adalah lansia dengan Hipertensi di Desa Jetiskarangpung. Sampel penelitian adalah total populasi sebanyak 90 lansia. Jenis penelitian Deskriptive korelatif dengan rancangan cross sectional. Hasil penelitian Aktifitas fisik dari 90 lansia kategori tidak aktif 13 lansia (14,4\%), kurang aktif 40 lansia (44,4 \%), cukup aktif 21 lansia (23,3\%), aktif 16 lansia (17,8\%). Hipertensi Systole, lansia hipertensi ringan 42 lansia (46,7\%), sedang 37 lansia (41,1\%), dan berat 11 lansia (12,2\%). Hipertensi Diastole, ringan 41 lansia (45,6 \%), sedang 48 lansia (53,3\%). Analisis hubungan menggunakan uji Chi Square, diketahui koefisien korelasi antara aktifitas fisik dan Hipertensi sistole adalah -0,700, nilai asymp sig $(p)=0,000$, dimana $(p)=0,000<\alpha=0,05$. Koefisien korelasi antara aktifitas fisik dan Hipertensi diastole adalah -0,038, nilai asymp sig $(p)=$ 0,002 , dimana $(p)=0,002<\alpha=0,05$. Kesimpulannya ada hubungan antara aktifitas fisik dengan Hipertensi (baik systole maupun diastole). Semakin aktif aktifitas fisiknya semakin normal tekanan darah baik pada Hipertensi Sistole maupun Diastole, dan semakin tidak aktif aktifitas fisiknya semakin tinggi tekanan darah baik pada Hipertensi systole maupun diastole.
\end{abstract}

Kata Kunci: Aktifitas fisik, hipertensi, lansia.

\begin{abstract}
Physical activity is every body movement of musculoskeletal system that needs energy. Hypertension is condition where systole and diastole pressure is more than normal scale (systole is more than $140 \mathrm{mmHg}$ and diastole is more than $90 \mathrm{mmHg}$ ) (Muwarni, 2011: 81). The aim of this study is to find the relationship of physical activities and hypertension of the eldery in Jetiskarangpung. The population of study was all eldery in Jetiskarangpung. The sample was 90 elderies. This study used descriptive correlative with cross sectional design. The result of the study was 13 elderies were not physically active (14,4\%), 40 elderies were less physically active $(44,4$ $\%), 21$ elderies were average physically active (23,3\%) and 16 elderies were physically active $(17,8 \%)$. The systole hypertension was low hypertension were 42 ederies $(46,7 \%$. The average hypertension were 37 elderies, $(41,1 \%)$ and severe hypertension were 11 elderies $(12,2 \%)$. The diastole hypertension, low hypertension were 41 elderies (45,6 \%), average hypertension were 37 elderies (53,5\%). Chi Square was used to find the relationship between physical activity and sistole hypertension, the index was -0,700, with asymp sig $(p)=0,000$, where $(p)=0,000<\alpha$ $=0,05$. Corelation coefficient between physical activities and diastole hypertension was $-0,038$ with asymp sig $(p)=0,002$, where $(p)=0,002<\alpha=0,05$. The conclusion is there is a relationship between physical activities and hypertension (systole and diastole). The more active of physical activities, the diastole and systole pressure is normal. The less active of physical activities, the sistole and diastole pressure will be higher.
\end{abstract}

Keywords: Physical activities, hypertension, elderies. 


\section{PENDAHULUAN}

Hipertensi adalah suatu keadaan dimana tekanan sistol dan diastol mengalami kenaikan yang melebihi batas normal tekanan (tekanan sistol diatas $140 \mathrm{mmHg}$ dan diastol diatas 90 mmHg) (Murwani, 2011 :81). Kejadian di Indonesia telah mencapai $31,7 \%$ dari total penduduk dewasa. Data itu di dapat dari hasil survei riset kesehatan dasar Riskesdas 20072008. Hanya sekitar $0,4 \%$ dari $31,7 \%$ kasus yang meminum obat hipertensi untuk pengobatan. Rendahnya penderita hipertensi untuk berobat dikarenakan hipertensi atau darah tinggi tidak menunjukkan gejala atau tanda khas yang bisa dipakai sebagai peringatan dini. Terdapat $76 \%$ kasus hipertensi di masyarakat yang diprediksi belum terdiagnois. Hipertensi kini telah menjelma sebagai penyakit penyebab kematian nomor tiga setelah stroke dan tuberkolosis di negara ini. Jumlahnya mencapai $6,9 \%$ dari proporsi penyebab kematian pada semua umur di Indonesia.

Aktifitas fisik adalah setiap gerakan tubuh yang dihasilkan oleh otot rangka yang memerlukan pengeluaran energi. Kurangnya aktifitas fisik merupakan faktor risiko indepeden untuk penyakit kronis dan secara keseluruhan diperkirakan dapat menyebabkan kematian secara global.

Hasil study pendahuluan menunjukkan di Desa Jetis karangpung, Kecamatan Kalijambe, Kabupaten Sragen ada 157 lansia mengalami penyakit gangguan degeneratif, dan 57\% lansia (90 lansia) penyakit degeneratif yang dialami adalah Hipertensi. Tujuan penelitian ini mengetahui hubungan aktivitas fisik dan Hipertensi pada Lansia di Desa Jetiskarangpung, Kecamatan Kalijambe, Sragen.

\section{METODE PENELITIAN}

Jenis penelitian yang digunakan dalam penelitian ini adalah deskriptive korelatif dengan rancangan cross sectional. Populasi dalam penelitian ini adalah lanjut usia di Desa Jetiskarangpung, Kecamatan Kalijambe, Kabupaten sragen yang berusia 55 tahun keatas yang mengalami Hipertensi dengan jumlah 90 lansia. Sampel penelitian ini total populasi ada 90 lansia. Analisis data yang digunakan untuk menguji hipotetis yaitu menggunakan Statistik menggunakan uji Chi Square

\section{HASIL DAN PEMBAHASAN Aktifitas Fisik}

Aktifitas fisik disajikan dalam tabel berikut ini:

Tabel 1. Distribusi Frekuensi Aktifitas Fisik

\begin{tabular}{ccc}
\hline Aktifitas Fisik & f & Presentase (\%) \\
\hline Tidak aktif & 13 & 14.4 \\
Kurang aktif & 40 & 44.4 \\
Cukup aktif & 21 & 23.3 \\
Aktif & 16 & 17.8 \\
Total & 90 & 100.0 \\
\hline
\end{tabular}

Adapun hipertensi pada lansia disajikan dalam tabel dibawah ini:

Tabel 2. Distribusi Frekuensi Hipertensi Sistole

\begin{tabular}{ccc}
\hline Hipertensi sistole & f & Presentase (\%) \\
\hline Ringan & 42 & 46.7 \\
Sedang & 37 & 41.1 \\
Berat & 11 & 12.2 \\
Total & 90 & 100.0 \\
\hline
\end{tabular}

Hipertensi systole pada responden selain disajikan dalam tabel juga disajikan dalam gambar berikut ini:

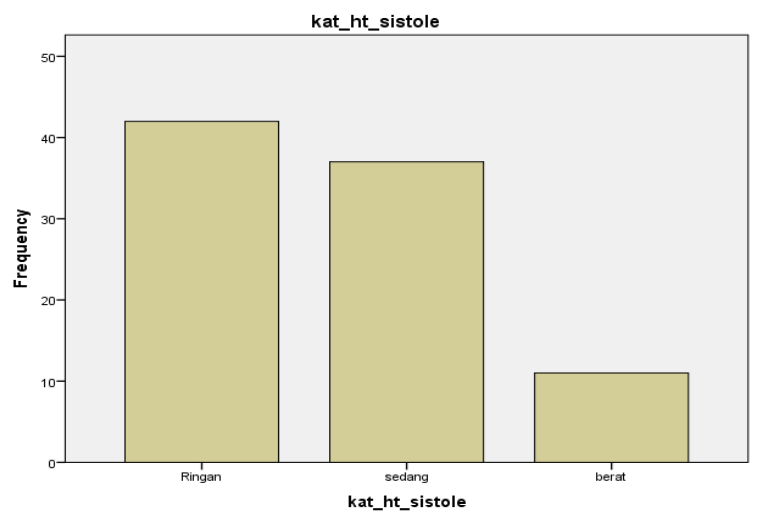

\section{Gambar 1: Distribusi Frekuensi Hipertensi} Diasyole

Diketahui bahwa dari 90 lansia yang melakukan aktifitas kategori tidak aktif ada 13 lansia $(14,4 \%)$, kurang aktif ada 40 lansia $(44,4 \%)$, cukup aktif ada 21 lansia (23,3\%), aktif ada 16 lansia $(17,8 \%)$. Hipertensi sistole diketahui dari 90 pasien yang mengalami Hipertensi Sistole (tekanan darah systole lebih $140 \mathrm{mmHg}$ ) yang termasuk kategori hipertensi ringan ada 42 lansia 
(46,7\%), hipertensi sedang 37 lansia (41,1\%), dan yang mengalami hipertensi berat 11 lansia $(12,2 \%)$. Distribusi frekuensi tekanan darah diastole dari 90 lansia yang mengalami Hipertensi diastole (tekanan darah diastole lebih dari $90 \mathrm{mmHg}$ ) yang termasuk kategori hipertensi ringan ada 41 lansia (45,6 \%), hipertensi sedang 48 lansia $(53,3 \%)$, dan tidak ada lansia yang mengalami hipertensi berat.

\section{ANALISIS}

Analisa korelasi menggunakan program IBM SPSS Statistic 23. Uji analisis yang dilakukan untuk mencari hubungan antara tingkat aktifitas fisik dan Hipertensi menggunakan uji Chi Square.

Berdasarkan tabel korelasi diatas dapat diketahui koefisien korelasi antara aktifitas fisik dan tekanan darah:systole adalah $-0,700$, nilai asymp sig $(\mathrm{p})=0,000$. Daerah kritis H0 ditolak jika nilai asymp sig $(\mathrm{p})<$ nilai $\alpha$. Oleh karena nilai asymp sig $(\mathrm{p})=0,000<\alpha=0,05$ maka H0 ditolak yang berarti bahwa ada hubungan antara aktifitas fisik dengan Tekanan darah Sistole (Hipertensi Sistole). Semakin aktif aktifitas fisiknya semakin normal tekanan darah sistolenya, dan semakin tidak aktif aktifitas fisiknya semakin tinggi tekanan darah sistolenya.

Koefisien korelasi antara aktifitas fisik dan tekanan darah: diastole adalah $-0,038$, nilai asymp sig $(p)=0,002$. Daerah kritis H0 ditolak jika nilai asymp sig $(\mathrm{p})<$ nilai $\alpha$. Oleh karena nilai asymp sig $(\mathrm{p})=0,002<\alpha=0,05$ maka $\mathrm{H} 0$ ditolak yang berarti bahwa ada hubungan antara aktifitas fisik dengan Tekanan darah Diastole (Hipertensi Diastole). Semakin aktif aktifitas fisiknya semakin normal tekanan darah diastolenya, dan semakin tidak aktif aktifitas fisiknya semakin tinggi tekanan darah diastolenya.

\section{PEMBAHASAN}

Hasil penelitian ini menunjukkan bahwa dari 90 lansia yang mengalami hipertensi di Desa Jetiskarangpung, Kalijambe, Kabupaten Srgen mayoritas kurang aktif dalam melakukan aktifitas fisik yaitu ada 40 lansia (44,4 \%), bahkan ada yang tidak aktif yaitu ada 13 lansia (14,4\%), kurang aktif. Lansia di Desa Jetis Karangpung yang sudah tidak bekerja rata hanya mengisi waktunya duduk-duduk melihat televise dan aktivitas didalam rumah saja. Hal tersebut dimungkinkan karena adanya proses menua pada lanjut usia. Semakin lanjut usia maka kemam- puan fisiknya akan semakin menurun, sehingga dapat mengakibatkan timbulnya gangguan dalam memenuhi kebutuhan hidupnya. Hal ini sejalan dengan penelitian yang dilakukan oleh Laelasari (2015) bahwa terdapat hubungan antara faktor usia dengan aktifitas fisik lansia. Dan di Desa Jetiskarangpung ini belum ada wadah lansia seperti posyandu lansia yang salah satu kegiatannya biasanya aktifitas fisik seperti senam lansia, senam strok dan lain-lain.

Lansia di Desa Jetiskarangpung ini yang cukup aktif ada 21 lansia (23,3\%), aktif ada 16 lansia $(17,8 \%)$. Hal ini memungkinkan karena lansia yang masih mampu bekerja mereka beraktifitas mengasuh cucu, memberihkan rumah, bersepeda dan berkebun atau bertani. Selaras dengan teori Haskell et all (2007) yang menyatakan bahwa aktifitas fisik yang dilakukan secara teratur terbukti dapat meningkatkan kualitas hidup secara fisik dan mental seseorang, aktifitas fisik yang baik dilakukan oleh lansia antara lain berjalan kaki, dan senam lansia. Hal ini sejalan dengan penelitian yang dilakukan oleh Aisah (2014) yang menyatakan bahwa terdapat hubungan antara senam lansia terhadap aktifitas sehari-hari.

Lansia di Desa Jetiskarangpung diketahui dari 90 lansia mengalami Hipertensi Sistole (tekanan darah systole lebih $140 \mathrm{mmHg}$ ) yang termasuk kategori hipertensi ringan ada 42 lansia (46,7 \%), hipertensi sedang 37 lansia $(41,1 \%)$, dan yang mengalami hipertensi berat 11 lansia $(12,2 \%)$.

Dilihat dari tekanan darah diastolenya dari 90 lansia yang termasuk kategori hipertensi ringan ada 41 lansia $(45,6 \%)$, hipertensi sedang 48 lansia $(53,3 \%)$, dan tidak ada lansia yang mengalami hipertensi berat.

Sangat dimungkinkan lansia mengalami hipertensi systole maupun diastole karena lanjut usia adalah suatu proses alami yang ditandai dengan penurunan fisik. Fatmah (2010) mengungkapkan penuaan adalah proses alamiah dan berkesinambungan yang mengalami perubahan anatomis, fisiologis, dan biokimia yang akan mempengaruhi fungsi dan kemampuan tubuh secara keseluruhan. Orang lanjut usia pada lazimnya secara fisiologis adalah normal memiliki nilai tekanan darah yang tinggi. Selain karena mengurangi aktifitasnya di usia senja, kondisi ini juga terjadi karena dinding arteri lansia telah menebal dan kaku karena arteriosclerosis sehingga darah dipaksa untuk melalui 
pembuluh yang sempit daripada biasanya dan menyebabkan naiknya tekanan. Penyakit tekanan darah tinggi / hipertensi tersebut kini semakin sering dijumpai pada orang lanjut usia (Nina, 2007).

Penelitian ini menunjukkan bahwa ada hubungan yang signifikan antara tingkat aktifitas fisik dan Hipertensi. Semakin aktif aktifitas fisiknya semakin normal tekanan darah baik pada Hipertensi Sistole maupun Diastole, dan semakin tidak aktif aktifitas fisiknya semakin tinggi tekanan darah baik pada Hipertensi systole maupun diastole.

\section{SIMPULAN}

1. Aktifitas fisik lannjut usia di Desa Jetiskarangpun rata-rata kurang, terutama lansia yang sudah tidak bekerja. Di Desa Jetiskarangpung juga belum ada wadah untuk lansia seperti posyandu lansia yang dapat memberikan aktifitas fisik seperti senam lansia, senam strok dan lain-lain. Kurangnya aktifitas fisik yang dilakukan lansia mengakibatkan lansia di Desa Jetiskarangpung berada pada kategori kurang aktif.

2. Hipertensi yang dialami lansia, didesa Jetis Karangpung baik sistole maupun diastole berfariasi dari ringan, sedang dan berat.

3. Terdapat hubungan antara tingkat aktifitas fisik dan Hipertensi pada lansia.

\section{REFERENSI}

Aisah, S. 201). Pengaruh senam lansia terhadap aktifitas sehari-hari pada lansia di Desa Mijen Ungaran Kelurahan Gedanganak Kecamatan Ungaran Timur. Skripsi. http://perpusnwu.web.id/karyailmiah/doc uments/3815.pdff diakses 1 Juni 2016.13.14.

Fatmah. 2010. Gizi Lanjut Usia. Jakarta: Erlangga.

Haskell WL, Lee IM, Pate RR, Powell, Blair SN, Franklin BA, et al. 2007. Physical activity and public health: updated recomendation for adults from the american colege of sport medicine and the american heart association. American colege of sports medicine and the american heart association, 14, 23-34.

Laelasari. 2015. Faktor-faktor yang berhubungan dengan aktifitas fisik lansia di posbindu anggrek wilayah kerja puskesmas Sindangjaya Kota Bandung. Skripsi. https://www.scribd.com/doc/280038087/j urnal. di akses 12 November 2016. 14.22.

Murwani, A. 2011. Perawatan Pasien Penyakit dalam. Jogyakarta : Gosyen Publishing

Nina, W. 2007. It's Never Too Late: Physical Activity and Elderly. 